\title{
The Effect of Mathematics Distance Learning by Google Classroom against Self Efficacy and Critical Mathematical Thinking Skills
}

\author{
Megawati \\ Mathematic Education Department, Postgraduate, Universitas Jambi-Indonesia \\ Email: megawatisman6@gmail.com \\ Damris \\ Science Education Department, Postgraduate, Universitas Jambi-Indonesia \\ Email: damrism@gmail.com \\ Kamid \\ Mathematic Education Department, Postgraduate, Universitas Jambi-Indonesia \\ Email: kamid.fkip@unja.ac.id
}

DOI: 10.31364/SCIRJ/v8.i10.2020.P1020813

http://dx.doi.org/10.31364/SCIRJ/v8.i10.2020.P1020813

\begin{abstract}
This study aims to look at the effect of the implementation of distance learning mathematics using the Google classroom application on self-efficacy and mathematical critical thinking skills. This study uses a quantitative approach that focuses on one group that is given special treatment in the form of mathematics learning using the Google Classroom application. The sample used in this study was students at the Senior High School level, totaling 62 students. The research was carried out during February-April 2020 at Muaro Jambi Public High School. Based on the results of the statistical tests above, it appears that mathematics learning using the Google classroom application affects the self-efficacy and critical thinking skills of students. If self-efficacy and mathematical critical thinking skills are understood as one element of learning outcomes, then mathematics learning using the Google classroom application can also be said to affect student learning outcomes. Thus it can clearly be said that learning mathematics using the Google classroom application can be used as alternative learning during the COVID-19 pandemic.
\end{abstract}

Keywords: mathematics distance learning, Google classroom, self-efficacy, mathematical critical thinking.

\section{INTRODUCTION}

Mathematics is one of the compulsory subjects that must be studied by all Indonesian students even in the world from basic education to secondary and higher education. This can be understood, considering that mathematics is one of the most useful and related sciences in almost all fields of human life, and is the mother of natural sciences (Liberna, 2012). Mathematics is one of the sciences that encourages and trains a person to have high-level thinking skills (Dinni, 2018), including the ability to think creatively and problem-solving abilities (Mursidik, Samsiyah, and Rudyanto, 2015), and critical thinking skills (Prihartini, Lestari, and Saputri, 2016). All of these capabilities are needed to improve the quality of human suction.
Associated with the emergence of dangerous and deadly infectious diseases, namely Corona Virus Diseases or known as COVID-19 (Velavan and Meyer, 2020) and (Kannan, Shaik Syed Ali, Sheeza, and Hemalatha, 2020) have an impact on the implementation of learning in school. This happens because many countries, including Indonesia, have implemented workfrom-home (WFH) policies, learning from home ( $\mathrm{LFH})$, social distancing and physical distancing, and even lockdown policies (Yunus and Rezki, 2020) so that the teaching-learning process is carried out remotely via online or virtual with the help of internet networks (Telaumbanua, 2020)

One alternative in carrying out distance learning models through online or virtual with the help of the internet network, through Google classroom (Asnawi, 2018). Google Classroom is an application that allows the formation of classes in cyberspace (Utami, 2019). Google classroom was chosen because it has many features or advantages compared to other applications. Some of the advantages of the Google classroom application: 1) the ease of accessing applications, through devices or smartphones owned by students, 2) this application allows teachers to send reading assignments or literacy materials to all students quickly in one click, 3) teachers can utilize this application as a discussion room for literacy with students simultaneously so that teachers can monitor student literacy activities, 4) through Google classroom teachers can instruct, assign, and discuss with students online at the same time simultaneously by virtual classrooms (Sutrisna, 2018).

Besides learning through the Google classroom application can also increase the independence of student learning (Vilmala, 2019). Therefore, during the COVID-19 pandemic and the implementation of learning from home mathematics learning was carried out using the help of the Google classroom application. It is hoped that the implementation of distance learning mathematics using Google classroom will not reduce the quality of learning and the quality of student learning outcomes. 
One of the most important learning outcomes is selfefficacy, which is an individual's belief or belief to master and create positive things in achieving an expected goal and being able to face problems in him (Kustanti and Pradita, 2018). Self-efficacy is the result of cognitive processes in the form of decisions, beliefs, or expectations about the extent to which an individual estimates his ability to carry out certain tasks or actions needed to achieve the desired results (Putra, Daharnis, and Syahniar, 2013). Self-efficacy is the belief that a person can use facilities efficiently leading to the desired state (Flammer, 2015).

Good self-efficacy will affect the quality of one's life (Kurniawan, Andini, and Agustin, 2019). Other research results also state that someone with good self-efficacy will be able to organize themselves for a better life (Muharrani, 2012). Subsequent research also mentions that self-efficacy has a positive effect on a sense of optimism, social welfare, and psychology (Prayogi, F., Muslihati, Handarini, 2017). In the learning process, including learning mathematics, self-efficacy is very influential in learning outcomes or achievements (Merolla, 2017). A student with good self-efficacy will have the ability to solve mathematical problems better than students who have low self-efficacy (Hidayat and Mutakin, 2015). Besides, self-efficacy also affects one's mathematical communication skills (Nurdiana, Pujiastuti, and Sugiman; 2018).

To improve the self-efficacy of students, it needs to be done in a tangible, planned, and systematic manner. The development of self-efficacy can be done in various ways, for example by training by using certain models (Gama Jpp, Ardiyanti, and Alsa, 2015) and (Yaqin, Niken, and Dharmana, 2017), through group guidance services (Putra et al., 2013). In the context of education is the process of learning in the classroom, self-efficacy can be improved by applying certain learning models, for example with problem-based learning models (Sariningsih and Purwasih, 2017), and constructive generative learning models (Minarti and Nurfauziah, 2016).

In addition to self-efficacy, other learning outcomes that are no less important are mathematical thinking abilities. Mathematical thinking ability is defined as a mental activity in carrying out mathematical processes or mathematical tasks. Mathematical thinking ability includes concept understanding, problem-solving, reasoning, and proof, communication, connection, and representation (Abdullah, 2013). The ability to think critically mathematically is an ability that is very important for everyone who is used to solve life problems by thinking seriously, actively, thoroughly in analyzing all the information they receive by including rational reasons so that every action to be taken is right (Liberna, 2012). The same thing was also conveyed by (Prihartini et al., 2016), that one of the abilities that are very important to be owned and developed by students is the ability to think critically. This capability is needed to solve everyday problems and problems in the future. The ability to think critically can help in thinking rationally in overcoming the problems that are facing and looking for and developing alternative solutions to these problems (Karim and Normaya, 2015) and Noordyana (2018).

Based on the description above, the focus of this study is to answer the question of how the influence of distance mathematics learning with the help of Google classroom on self-efficacy and mathematical critical thinking skills of students through.

\section{RESEARCH METHODS}

This study uses a quantitative approach with a quasiexperimental method in a quasi-experimental design without a control group or pretest (Hastjarjo, 2019). Thus, this study focuses on one group that is given special treatment in the form of mathematics learning using the Google Classroom application. The sample used in this study were students at the Senior High School level, totaling 62 students. The research was carried out during February-April 2020 at 6 Muaro Jambi Public High School. The instrument used to obtain data on self-efficacy and the ability to think critically mathematically is a questionnaire. The instrument consisted of 20 questions that were adjusted to the indicators of self-efficacy and mathematical critical thinking skills. Thus, the minimum score of each variable is 0 and the maximum score is 20. Data analysis was performed by linear analysis using a productmoment correlation. Thus the hypothesis in this study are:

Ha1: There is an effect of using the Google classroom application on student self-efficacy

Ho1: There is no effect of using the Google classroom application on student self-efficacy

Ha2: There is an influence of the use of the Google classroom application on students' mathematical critical thinking skills

Ho2: There is no effect of using the Google classroom application on students' mathematical critical thinking skills

Decision making is based on the value of sig. test carried out on the T-test. If a sig value is obtained on the t-test results $<0.05$ (level 5\%) then $\mathrm{Ho}$ is rejected and $\mathrm{H} 1$ is accepted.

\section{III.RESULTS AND DISCUSSION}

Based on the students' test results after the implementation of learning using the Google classroom application, then they are given a test to measure the selfefficacy and critical thinking skills of each student's mathematics. The data obtained were then analyzed using SPSS 16 software. The initial step of the analysis was to look at the normality level of the self-efficacy variable data and the mathematical critical thinking ability. The data normality test results can be seen in Tables $1 \mathrm{a}$ and $1 \mathrm{~b}$ below:

Table 1a. Self-Efficacy data normality test

\begin{tabular}{|c|c|c|c|c|c|c|}
\hline & \multicolumn{3}{|c|}{$\begin{array}{l}\text { Kolmogorov- } \\
\text { Smirnov }^{\mathrm{a}}\end{array}$} & \multicolumn{3}{|c|}{ Shapiro-Wilk } \\
\hline & Statistic & df & Sig. & Statistic & $\mathrm{df}$ & Sig. \\
\hline $\begin{array}{l}\text { Self- } \\
\text { Efficacy }\end{array}$ & .127 & 62 & .014 & .972 & 62 & .160 \\
\hline
\end{tabular}

www.scirj.org

(C) 2020, Scientific Research Journal

http://dx.doi.org/10.31364/SCIRJ/v8.i10.2020.P1020813

This publication is licensed under Creative Commons Attribution CC BY. 
Table 1b. Data normality test of mathematical critical thinking ability

Tests of Normality

\begin{tabular}{|l|r|r|r|r|r|r|}
\hline \multirow{2}{*}{} & \multicolumn{3}{|c|}{$\begin{array}{c}\text { Kolmogorov- } \\
\text { Smirnov }\end{array}$} & \multicolumn{3}{c|}{ Shapiro-Wilk } \\
\cline { 2 - 7 } & Statistic & df & Sig. & Statistic & df & Sig. \\
\hline $\begin{array}{l}\text { Critical } \\
\text { Mathematics }\end{array}$ & .170 & 61 & .000 & .930 & 61 & .202 \\
\hline
\end{tabular}

Based on the results of the normality test data as Tables $1 \mathrm{a}$ and $1 \mathrm{~b}$ above, it was seen that the two variables (selfefficacy and mathematical critical thinking ability) were normally distributed. This is based on the sig value of the two variables respectively 0.014 and 0.000 which means less than 0.005 , so it can be said to be normally distributed.

Data normality test results as described above, then used as a basis for continuing on the analysis of the onesample test, with a reference number 15 which means that about $75 \%$ of students have self-efficacy and critical thinking skills are at a good level after the implementation of mathematics learning with using the Google classroom application. In other words, it can be said that learning with the Google classroom application is said to affect if $75 \%$ of students have good self-efficacy and mathematical critical thinking skills. As for the results of data testing using SPSS 16 software, it produces the data as shown in Tables $2 a$ and $2 b$ below:

Table 2a. The effect of learning mathematics in the google classroom application on self-efficacy.

One-Sample Test

\begin{tabular}{|c|c|c|c|c|c|c|}
\hline & \multicolumn{6}{|c|}{ Test Value $=15$} \\
\hline & \multirow[b]{2}{*}{$\mathrm{t}$} & \multirow[b]{2}{*}{$\mathrm{df}$} & \multirow{2}{*}{$\begin{array}{l}\text { Sig. (2- } \\
\text { tailed) }\end{array}$} & \multirow{2}{*}{$\begin{array}{c}\text { Mean } \\
\text { Difference }\end{array}$} & \multicolumn{2}{|c|}{$\begin{array}{l}\text { 95\% Confidence } \\
\text { Interval of the } \\
\text { Difference }\end{array}$} \\
\hline & & & & & Lower & Upper \\
\hline \begin{tabular}{|l} 
Self- \\
Efficacy
\end{tabular} & 10.759 & 61 & .000 & 4.06452 & 3.3091 & 4.8199 \\
\hline
\end{tabular}

Based on the value of sig. (2-tailed) obtained a value of $0,000<0.05$, then $\mathrm{Ho}$ is rejected and $\mathrm{Ha}$ is accepted, there is an effect of using the Google classroom application on the self-efficacy of students.
Table $2 b$. The effect of learning mathematics in the Google classroom application on mathematical critical thinking skills.

One-Sample Test

\begin{tabular}{|c|c|c|c|c|c|c|}
\hline & \multicolumn{6}{|c|}{ Test Value $=15$} \\
\hline & \multirow[b]{2}{*}{$\mathrm{t}$} & \multirow[b]{2}{*}{$\mathrm{df}$} & \multirow{2}{*}{$\begin{array}{l}\text { Sig. (2- } \\
\text { tailed) }\end{array}$} & \multirow{2}{*}{$\begin{array}{c}\text { Mean } \\
\text { Difference }\end{array}$} & \multicolumn{2}{|c|}{$\begin{array}{l}95 \% \text { Confidence } \\
\text { Interval of the } \\
\text { Difference }\end{array}$} \\
\hline & & & & & Lower & Upper \\
\hline $\begin{array}{l}\text { Critical } \\
\text { Mathematics }\end{array}$ & 14.759 & 61 & .000 & 4.06452 & 3.4091 & 6.2199 \\
\hline
\end{tabular}

Based on the value of sig. (2-tailed) obtained a value of $0,000<0.05$, then Ho is rejected and $\mathrm{Ha}$ is accepted, there is an influence of the use of the Google classroom application on the Critical Mathematics of students. Based on the results of the statistical tests above, it appears that mathematics learning using the Google classroom application affects the selfefficacy and critical thinking skills of students. If self-efficacy and mathematical critical thinking skills are understood as one element of learning outcomes, then mathematics learning using the Google classroom application can also be said to affect student learning outcomes. Thus it can clearly be said that learning mathematics using the Google classroom application can be used as alternative learning during the COVID-19 pandemic.

The findings in this study are also in line with the results of previous research, for example, research conducted by Nirfayanti and Nurbaeti (2019) that learning mathematicsreal analysis using the Google classroom application can increase student motivation. Besides, Sutrisna (2018) also found that the google classroom application that is utilized in the learning process can improve student literacy skills. Kurniawati, Santanapurba, and Kusumawati, (2019) research results and Ernawati (2018) also produced findings that student learning outcomes were in the sufficient category, there were differences in learning outcomes between male and female students, and student responses were in the category very high. Thus, it can be said that the results of previous studies have strengthened the results in this study, namely that learning by using the Google Classroom application has a positive impact on student learning outcomes.

Viewed from the perspective of the self-efficacy variable, mathematics learning has a positive effect on the variable. That means that learning by using the Google Classroom application has been able to increase students' confidence in their ability to use the application to learn mathematics. One factor that is allegedly able to influence the level of confidence (self-efficacy) of participants in the process of learning mathematics using the Google Classroom application is the simple features of the application itself. According to Asnawi (2018) that this application provides a set 
of advanced features that make it an ideal tool for use with students. This application helps teachers save time, keep classes organized, and improve communication with students. Besides, Qomariah, Nursobah, and Lailiyah (2019), also said that with the Google classroom application students can study, listen, read, send assignments, remotely. Hendriana and Kadarisma (2019) Research results also show that mathematics learning itself can increase students' self-efficacy.

When viewed for the mathematical critical thinking ability, learning mathematics using the Google classroom application is suspected because there is a sense of curiosity and students' yearning towards the new suit. This is because the Google classroom application is one application that is applied in learning (mathematics) is still relatively new (Asnawi, 2018). Also, curiosity and curiosity over the use of the Google classroom application are thought to have influenced the results of this research. This is as the result of research Amalia and Pujiastuti (2013) which says that curiosity is influenced by the ability to think critically. Solehuzain and Dwidayati, (2017) also found that curiosity and critical thinking skills can be improved simultaneously, it means that the two have a close connection.

\section{IV.CONCLUSION}

Based on the results of the statistical tests above, it appears that mathematics learning using the Google classroom application affects the self-efficacy and critical thinking skills of students. If self-efficacy and mathematical critical thinking skills are understood as one element of learning outcomes, then mathematics learning using the Google classroom application can also be said to affect student learning outcomes. Thus it can clearly be said that learning mathematics using the Google classroom application can be used as alternative learning during the COVID-19 pandemic.

\section{ACKNOWLEDGMENTS}

This research has involved many parties, since the planning, implementation so that it came to the writing of reports and publications. To that end, the researchers would like to thank the mathematics learning development team with the Google classroom application for helping to adjust and compile teaching materials so that research can be carried out. The researchers also thanked the Principal of SMA 6 Muaro Jambi, who had supported virtual learning during the COVID19 pandemic so that the teaching and learning process remained virtual.

\section{REFERENCES}

Abdullah, I. H. (2013). Berpikir Kritis Matematik. Jurnal Matematika Dan Pendidikan Matematika.

Amalia, N. F., \& Pujiastuti, E. (2013). Kemampuan berpikir kritis dan rasa ingin tahu melalui model pbl. In Seminar Nasional Matematika X Universitas Negeri Semarang 2016.

Asnawi, N. (2018). Pengukuran Usability Aplikasi Google Classroom Sebagai E-learning Menggunakan USE Questionnaire (Studi Kasus: Prodi Sistem Informasi UNIPMA). RESEARCH : Computer, Information System \& Technology
Management. https://doi.org/10.25273/research.v1i1.2451

Dinni, H. N. (2018). HOTS ( High Order Thinking Skills ) dan Kaitannya dengan Kemampuan Literasi Matematika. Prisma.

Ernawati. (2018). Pengaruh Penggunaan Aplikasi Google Classroom Terhadap Kualitas Pembelajaran Dan Hasil Belajar Siswa Pada Mata Pelajaran Ekonomi Kelas XI DI MAN 1 Kota Tangerang Selatan. Skripsi.

Flammer, A. (2015). Self-Efficacy. In International Encyclopedia of the Social \& Behavioral Sciences: Second Edition. https://doi.org/10.1016/B978-0-08-0970868.25033-2

Gama Jpp, E., Ardiyanti, D., \& Alsa, A. (2015). Pelatihan " PLANS " untuk Meningkatkan Efikasi Diri dalam Pengambilan Keputusan Karir. GADJAH MADA JOURNAL OF PROFESSIONAL PSYCHOLOGY.

Hastjarjo, T. D. (2019). Rancangan Eksperimen-Kuasi. Buletin Psikologi. https://doi.org/10.22146/buletinpsikologi.38619

Hendriana, H., \& Kadarisma, G. (2019). Self-Efficacy dan Kemampuan Komunikasi Matematis Siswa SMP. JNPM (Jurnal Nasional Pendidikan Matematika). https://doi.org/10.33603/jnpm.v3i1.2033

Hidayat, R. W., \& Mutakin, T. Z. (2015). Pengaruh efikasi diri (self efficacy) terhadap kemampuan pemecahan masalah matematika. EduResearch.

Kannan, S., Shaik Syed Ali, P., Sheeza, A., \& Hemalatha, K. (2020). COVID-19 (Novel Coronavirus 2019) - recent trends. European Review for Medical and Pharmacological Sciences. https://doi.org/10.26355/eurrev_202002_20378

Karim, K., \& Normaya, N. (2015). Kemampuan Berpikir Kritis Siswa dalam Pembelajaran dalam Pembelajaran Matematika dengan Menggunakan Model Jucama di Sekolah Menengah Pertama. EDU-MAT: Jurnal Pendidikan https://doi.org/10.20527/edumat.v3i1.634 Matematika.

Kurniawan, S. T., Andini, I. S., \& Agustin, W. R. (2019). Hubungan Self Efficacy Dengan Kualitas Hidup Pasien Gagal Ginjal Kronik Yang Menjalani Terapi Hemodialisa Di RSUD SUKOHARJO. Jurnal Kesehatan Kusuma Husada. https://doi.org/10.34035/jk.v10i1.346

Kurniawati, M., Santanapurba, H., \& Kusumawati, E. (2019). Penerapan Blended Learning Menggunakan Model Flipped Classroom Berbantuan Google Classroom Dalam Pembelajaran Matematika SMP. EDU-MAT: Jurnal Pendidikan https://doi.org/10.20527/edumat.v7i1.6827

Kustanti, C. Y., \& Pradita, R. (2018). Self Efficacy Penderita Hiv/Aids Dalam Mengkonsumsi Antiretroviral Di Lembaga Swadaya Masyarakat Kebaya Yogyakarta. Jurnal Kesehatan. https://doi.org/10.35913/jk.v5i1.74

LIBERNA, H. (2012). Peningkatan Kemampuan Berpikir Kritis Matematis Siswa Melalui Penggunaan Metode Improve Pada Materi Sistem Persamaan Linear Dua Variabel. Formatif.

www.scirj.org

(C) 2020, Scientific Research Journal

http://dx.doi.org/10.31364/SCIRJ/v8.i10.2020.P1020813

This publication is licensed under Creative Commons Attribution CC BY. 
Merolla, D. M. (2017). Self-efficacy and Academic Achievement. Sociological Perspectives. https://doi.org/10.1177/0731121416629993

Minarti, E. D., \& Nurfauziah, P. (2016). Pendekatan Konsturktivisme Dengan Model Pembelajaran Generatif Guna Meningkatkan Kemampuan Komunikasi Dan Koneksi Matematis Serta Self Efficacy Mahasiswa Calon Guru Di Kota Cimahi. P2M STKIP Siliwangi. https://doi.org/10.22460/p2m.v3i2p68-83.629

Muharrani, T. (2012). Hubungan antara Self-efficacy dengan Self-regulated Learning pada Mahasiswa Fakultas Psikologi Universitas Sumatera Utara. Repository.Usu.Acd.Id.

Mursidik, E. M., Samsiyah, N., \& Rudyanto, H. E. (2015). Kemampuan Berpikir Kreatif Dalam Memecahkan Masalah Matetatika Open-Ended Ditinjau Dari Tingkat Kemampuan Matematika Siswa Sekolah Dasar. PEDAGOGIA: Jurnal Pendidikan. https://doi.org/10.21070/pedagogia.v4i1.69

Nirfayanti, \& Nurbaeti. (2019). Pengaruh Media Pembelajaran Google Classroom Dalam Pembelajaran Analisis Real Terhadap Motivasi Belajar Mahasiswa. Proximal.

Noordyana, M. A. (2018). Meningkatkan Kemampuan Berpikir Kritis Matematis Siswa melalui Pendekatan Metacognitive Instruction. Mosharafa: Jurnal Pendidikan Matematika. https://doi.org/10.31980/mosharafa.v5i2.267

Nurdiana., H., Pujiastuti., E., \& Sugiman. (2018). Kemampuan Komunikasi Matematis Ditinjau dari Self-Efficacy Menggunakan Model Discovery Learning Terintegrasi Pemberian Motivasi. Jurnal PRISMA, Prosiding Seminar Nasional Matematika Universitas Negeri Semarang.

Prayogi, F., Muslihati, Handarini, D. M. (2017). Hubungan Self Efficacy, Optimism, Social Support Dan Psychological Well-Being Peserta Didik Smk. Jurnal Pendidikan: Teori, Penelitian, Dan Pengembangan. https://doi.org/OAJ-SHERPA/RoMEO-Google Scholar-IPI

Prihartini, E., Lestari, P., \& Saputri, S. A. (2016). Meningkatkan Kemampuan Berpikir Kritis Matematis Menggunakan Pendekatan Open Ended. Prosiding Seminar Nasional Matematika IX 2015.

Putra, S. A., Daharnis, D., \& Syahniar, S. (2013). Efektivitas Layanan Bimbingan Kelompok dalam Meningkatkan Self Efficacy Siswa. Konselor. https://doi.org/10.24036/02013221399-0-00

Qomariah, S., Nursobah, \& Lailiyah, S. (2019). Implementasi Pemanfaatan Google Classroom untuk Pembelajaran di Era Revolusi 4.0. Seminar Nasional Hasil Pengabdian Kepada Masyarakat 2019. https://doi.org/http://dx.doi.org/10.30700/sm.v1i1.573

Sariningsih, R., \& Purwasih, R. (2017). Pembelajaran Problem Based Learning Untuk Meningkatkan Kemampuan Pemecahan Masalah Matematis Dan Self Efficacy Mahasiswa Calon Guru. JNPM (Jurnal Nasional Pendidikan Matematika). https://doi.org/10.33603/jnpm.v1i1.275

Solehuzain, \& Dwidayati, N. K. (2017). Kemampuan Berpikir Kreatif dan Rasa Ingin Tahu pada Model Problem-Based Learning dengan Masalah Open Ended. 103 Ujmer.

Sutrisna, D. (2018). Meningkatkan Kemampuan Literasi Mahasiswa Menggunakan Google Classroom. FON: Jurnal Pendidikan Bahasa Dan Sastra Indonesia. https://doi.org/10.25134/fjpbsi.v13i2.1544

Telaumbanua, D. (2020). Urgensi Pembentukan Aturan Terkait Pencegahan Covid-19 di Indonesia. QALAMUNA: Jurnal Pendidikan, Sosial, Dan Agama. https://doi.org/10.37680/qalamuna.v12i01.290

Utami, R. (2019). Analisis Respon Mahasiswa terhadap Penggunaan Google Classroom pada Mata Kuliah Psikologi Pembelajaran Matematika. Prisma, Prosiding Seminar Nasional Matematika.

Velavan, T. P., \& Meyer, C. G. (2020). The COVID-19 epidemic. Tropical Medicine and International Health. https://doi.org/10.1111/tmi.13383

Vilmala, B. K. (2019). Pengembangan Perangkat Pembelajaran Blended Learning Melalui Aplikasi Google Classroom Untuk Peningkatan Kemandirian Belajar Mahasiswa. Journal of Education Informatic Technology and Science.

Yaqin, A., Niken, S., \& Dharmana, E. (2017). Efek Self Efficacy Training Terhadap Self Efficacy Dan Kepatuhan Diet Diabetesi. JI-KES (Jurnal Ilmu Kesehatan). https://doi.org/10.33006/ji-kes.v1i1.45

Yunus, N. R., \& Rezki, A. (2020). Kebijakan Pemberlakuan Lock Down Sebagai Antisipasi Penyebaran Corona Virus Covid-19. SALAM: Jurnal Sosial Dan Budaya Syar-I. https://doi.org/10.15408/sjsbs.v7i3.15083 